Article

\title{
Tuning $\mathrm{SnO}_{2}$ surface with $\mathrm{CuO}$ for soot particulate combustion: The effect of monolayer dispersion capacity on reaction performance
}

\author{
Jiating Shen a, Xiaohui Feng a, Rui Liu a , Xianglan Xu a, Cheng Rao a, Jianjun Liu b, Xiuzhong Fang a, \\ Chao Tan c, Youchang Xie d, Xiang Wang a,* \\ a Key Laboratory of Jiangxi Province for Environment and Energy Catalysis, College of Chemistry, Nanchang University, Nanchang 330031, Jiangxi, China \\ b Jiangxi Baoan New Material Technology Corporation, LTD, Pingxiang 337000, Jiangxi, China \\ c Key Laboratory of Process Analysis and Control of Sichuan Universities, Yibin University, Yibin 644000, Sichuan, China \\ ${ }^{\mathrm{d} C o l l e g e ~ o f ~ C h e m i s t r y ~ a n d ~ M o l e c u l a r ~ E n g i n e e r i n g, ~ P e k i n g ~ U n i v e r s i t y, ~ B e i j i n g ~ 100871, ~ C h i n a ~}$
}

\section{A R T I C L E I N F O}

\section{Article history:}

Received 29 January 2019

Accepted 12 March 2019

Published 5 June 2019

\section{Keywords:}

$\mathrm{CuO}$ supported on $\mathrm{SnO}_{2}$

Soot particulate combustion

Monolayer dispersion

$\mathrm{X}$-ray diffraction and X-ray photoelec-

tron spectroscopy extrapolation

Threshold effect

\begin{abstract}
A B S T R A C T
With the objective to investigate the structure-reactivity relationship of $\mathrm{CuO} / \mathrm{SnO}_{2}$ and eventually design more applicable catalysts for soot combustion, catalysts with different $\mathrm{CuO}$ loadings have been prepared by impregnation method. By using X-ray diffraction and X-ray photoelectron spectroscopy extrapolation methods, it is disclosed that $\mathrm{CuO}$ disperses finely on the $\mathrm{SnO}_{2}$ support to form a monolayer with a capacity of $2.09 \mathrm{mmol} 100 \mathrm{~m}^{-2}$, which equals $4.8 \mathrm{wt} \% \mathrm{CuO}$ loading. When the $\mathrm{CuO}$ loading is below the capacity, it is in a sub-monolayer state. However, when the loading is above the capacity, $\mathrm{CuO}$ micro-crystallites will be formed that coexist with the $\mathrm{CuO}$ monolayer. The soot combustion activity of the catalyst increases with the $\mathrm{CuO}$ loading until it reaches the monolayer dispersion capacity. A further increase in the $\mathrm{CuO}$ loading has no evident influence on the activity. Raman results have testified that with the addition of $\mathrm{CuO}$ onto the $\mathrm{SnO}_{2}$ support, a surface-active oxygen species can be formed, the amount of which also increases significantly with the increase in the $\mathrm{CuO}$ loading until it reaches the monolayer dispersion capacity. Increasing the $\mathrm{CuO}$ loading further has no evident impact on the amount of surface oxygen. Therefore, an apparent monolayer dispersion threshold effect is observed for soot combustion over $\mathrm{CuO} / \mathrm{SnO}_{2}$ catalysts. It is concluded that the amount of surface-active oxygen sites is the major factor determining the activity of the catalyst.
\end{abstract}

(C) 2019, Dalian Institute of Chemical Physics, Chinese Academy of Sciences. Published by Elsevier B.V. All rights reserved.

\section{Introduction}

In recent decades, the number of cars powered by diesel engines has significantly increased owing to their good dynamic performance [1,2]. However, the soot particulate emitted from diesel engines is one of the most hazardous pollutants that can cause severe environmental and health problems [3-5]. To eliminate soot particle pollution, filtering it with a DPF trap followed by catalytic oxidation is an efficient current strategy [6]. To meet the increasingly stringent emission regulations, it is still a major challenge to develop highly active and stable catalysts for soot particulate combustion, especially a catalyst

\footnotetext{
* Corresponding author. Tel: +86-15979149877; E-mail: xwang23@ncu.edu.cn

This work is supported by the National Natural Science Foundation of China $(21567016,21666020)$, the Natural Science Foundation of Jiangxi Province (20181ACB20005, 20171BAB213013, 20181BCD40004, 20181BAB203017), the Innovation Fund Designated for Graduate Students of Jiangxi Province (YC2018-B015), the Education Department Foundation of Jiangxi Province (KJLD14005), and the Opening Fund of Key Laboratory of Process Analysis and Control of Sichuan Universities (2017002), which are greatly acknowledged by the authors.

DOI: S1872-2067(19)63354-1 | http://www.sciencedirect.com/science/journal/18722067 | Chin. J. Catal., Vol. 40, No. 6, June 2019
} 
that can match the low exhaust temperature of diesel engines.

In the late 1970s, Xie et al. [7-9] found that a metal oxide can spontaneously disperse onto the surfaces of different supports to form a monolayer or sub-monolayer, which is a thermodynamically favored process that has been termed by them as "monolayer dispersion". A "close-packed model" has been proposed by them for calculating the ideal and maximum monolayer dispersion capacities of supported metal oxides on different supports. Moreover, X-ray diffraction (XRD), Raman, and X-ray photoelectron spectroscopy (XPS) extrapolation methods have been developed by them to quantify the real monolayer dispersion capacities of different supported systems. It is revealed that in most cases, the real monolayer dispersion capacity of a supported system is lower than the ideal value calculated by the "close-packed model" owing to the interaction between the supported component and the support [9]. Chen et al. [10-13] studied the dispersion of $\mathrm{CuO}$ and $\mathrm{MoO}_{3}$ on various supports such as $\mathrm{Al}_{2} \mathrm{O}_{3}, \mathrm{TiO}_{2}, \mathrm{CeO}_{2}$, and $\mathrm{CeO}_{2}-\mathrm{Al}_{2} \mathrm{O}_{3}$ etc. and found the same phenomenon. However, an "incorporation model" was proposed by them to explain the phenomenon. By using different supports, Wachs et al. [14-16] explored the dispersion behaviors of supported $\mathrm{MoO}_{3}$ and $\mathrm{V}_{2} \mathrm{O}_{5}$ and discovered a strong interaction between the supports and the supported metal oxides. On the basis of their work, the surface oxide-support interaction theory was proposed. In spite of the different terminologies used, all the researchers have found that when a metal oxide is loaded onto a support, the monolayer dispersion phenomenon is commonly observed, and the monolayer capacity can be quantified by different methods. Furthermore, when a supported system is used as a catalyst for a certain reaction, a monolayer dispersion threshold effect is generally observed. In more detail, a catalyst with a monolayer dispersed active component generally shows some special reaction performance, such as the highest activity and selectivity [14]. Nowadays, monolayer dispersion has been well accepted and has become an important theory in the design of highly functional catalytic materials.

Numerous studies have proved that $\mathrm{CuO}$ is very active towards many catalytic oxidation reactions [17-23]. For instance, the famous Hopcalite catalyst, which typically consists of $30 \%-40 \%$ copper oxide and $60 \%-70 \%$ manganese oxide, displays superior activity for $\mathrm{CO}$ oxidation at room temperature and has been practically used $[17,18]$. For $\mathrm{CO}$ oxidation on $\mathrm{CuO}$, Boronin et al. [19] found that $\mathrm{O}^{-}$species is responsible for its superior CO oxidation activity. Kakuta et al. [20] found that when starting from stoichiometric $\mathrm{CuO}$, the valency of the surface copper cycles as per $\mathrm{Cu}^{2+} \rightleftharpoons \mathrm{Cu}^{0}$ during the reaction process, which might determine the reaction rate. In contrast, Tikhov et al. [21] revealed that $\mathrm{Cu}^{+}$clusters at the outlets of surface defects, which are paths for quick oxygen migration from the $\mathrm{CuO}$ bulk, are active sites that account for the $\mathrm{CO}$ oxidation activity. Through DFT calculation, Sun et al. [22] investigated the adsorption and dissociation of molecular $\mathrm{O}_{2}$ on $\mathrm{CuO}$ (111) surface. It was disclosed that both the surface species $\mathrm{O}_{2}{ }^{2-}$ and $\mathrm{O}_{2}-$ can be effectively formed as active oxygen sites.

Our earlier work also demonstrated that mesoporous copper-tin solid solutions prepared through coprecipitation [24] or hydrothermal method with KIT-6 as the hard template [25] show superior activity towards CO oxidation, owing to the formation of a large amount of surface-active oxygen species, high surface areas, and porous structures. Moreover, by using a colloidal crystal templating method, a 3DOM structured copper-tin solid solution catalyst can be obtained, which exhibits very good soot combustion activity because the coexistence of meso- and macro-pores favors the contact of soot particles with the surface-active oxygen species [26]. Therefore, in the work that continued, the structure-reactivity relationship of pure $\mathrm{CuO}$ for soot oxidation was particularly investigated [27]. It was discovered that for $\mathrm{CuO}$ prepared by using different copper precursors and precipitants, four kinds of active sites with varied activities were present on the surface, but in different amounts. However, only the two kinds of active sites that are reducible by soot particulates below $500{ }^{\circ} \mathrm{C}$ contribute to soot oxidation. The mobility and abundance of surface oxygen are critical factors that control the soot oxidation activity of pure CuO catalysts.

However, bare $\mathrm{CuO}$ generally has low surface areas and physical stability, which restrict its feasibility as a catalyst for most of the exothermic processes such as soot combustion, where it experiences deactivation [27]. $\mathrm{SnO}_{2}$ is a typical n-type semiconductor that has a high melting point of $1630{ }^{\circ} \mathrm{C}$ [28]. Many earlier studies, including those of our group, have proved that it has not only abundant surface-deficient oxygen species, but also good physical stability [29]. Therefore, $\mathrm{SnO}_{2}$ could be an appropriate support for many active components in the preparation of catalysts for reactions that require good stability more than a high intrinsic activity, e.g., some strong exothermic processes such as soot and VOC combustion. However, its properties as a catalyst support have been rarely investigated. With the objective to understand the interfacial interaction between $\mathrm{CuO}$ and $\mathrm{SnO}_{2}$, and eventually realize more applicable catalysts for real soot combustion processes, in this study, a series of $\mathrm{CuO} / \mathrm{SnO}_{2}$ catalysts have been prepared and used for soot oxidation based on the monolayer dispersion theory. An evident monolayer dispersion threshold effect has been observed, and the catalysts with $\mathrm{CuO}$ loadings not below the monolayer dispersion capacity show the best activity towards soot oxidation. By using different characterization methods, the reasons for the observed activity have been elucidated in this work.

\section{Experimental}

\subsection{Catalyst preparation}

All the $\mathrm{CuO} / \mathrm{SnO}_{2}$ catalysts were prepared by the traditional impregnation method with a $\mathrm{Cu}\left(\mathrm{NO}_{3}\right)_{2}$ (Sinopharm Chemical Reagent Corporation, China) solution (0.58 M) acting as the precursor. In detail, a certain amount of CVD $\mathrm{SnO}_{2}$ (Shanghai Zaiyi New Material Co., Ltd., China) was added into the $\mathrm{Cu}\left(\mathrm{NO}_{3}\right)_{2}$ solution under constant stirring in a water bath at $80{ }^{\circ} \mathrm{C}$ for $3 \mathrm{~h}$. After evaporating the solvent water, the solids obtained were dried at $110^{\circ} \mathrm{C}$ overnight for approximately 12 $\mathrm{h}$ and then calcined at $550^{\circ} \mathrm{C}$ in air atmosphere for $4 \mathrm{~h}$, before 
being heated to the target temperature at the rate of $2{ }^{\circ} \mathrm{C} \mathrm{min}-1$. Afterwards, the samples were cooled to room temperature to obtain the final $\mathrm{CuO} / \mathrm{SnO}_{2}$ samples, which are labeled as $1 \%$ $\mathrm{CuO} / \mathrm{SnO}_{2}, 3 \% \mathrm{CuO} / \mathrm{SnO}_{2}, 5 \% \mathrm{CuO} / \mathrm{SnO}_{2}, 7 \% \mathrm{CuO} / \mathrm{SnO}_{2}, 9 \%$ $\mathrm{CuO} / \mathrm{SnO}_{2}, \quad 11 \% \quad \mathrm{CuO} / \mathrm{SnO}_{2}, \quad 13 \% \quad \mathrm{CuO} / \mathrm{SnO}_{2}$, and $15 \%$ $\mathrm{CuO} / \mathrm{SnO}_{2}$, according to their $\mathrm{CuO}$ loadings.

\subsection{Catalyst characterization}

The powder XRD patterns of the samples were recorded on a Bruker AXS D8Focus diffractometer operating at $40 \mathrm{kV}$ and $30 \mathrm{~mA}$ with a copper target and $K_{\alpha}$ radiation. The scans were collected over the $2 \theta$ range $20^{\circ}$ to $80^{\circ}$ in steps of $2^{\circ} \mathrm{min}^{-1}$.

XPS tests were carried out on a PerkinElmer PHI1600 system by using a single Mg-K X-ray source operating at $300 \mathrm{~W}$ and $15 \mathrm{kV}$. The spectra were obtained at ambient temperature and ultrahigh vacuum. The binding energies were calibrated by using the $\mathrm{C} 1 s$ peak of a standard graphite sample (at $284.8 \mathrm{eV}$ ) as the reference.

$\mathrm{N}_{2}$ adsorption-desorption experiments of the samples were performed at $-196^{\circ} \mathrm{C}$ on an ASAP2020 instrument. The specific surface areas of the catalysts were calculated by using the Brunauer-Emmett-Teller (BET) method in the relative pressure $\left(P / P_{0}\right)$ range $0.05-0.25$. The pore size distributions of the samples were calculated through the Barrett-Joyner-Halenda method. Furthermore, the pore sizes were obtained from the peak positions of the distribution curves. The total pore volume was calculated at the relative pressure of $P / P_{0}=0.99$.

Raman spectra of the catalysts were recorded on a Renishaw inVia Raman spectrometer equipped with an argon laser excitation source (532 nm) and a Renishaw RenCam CCD detector. The scanned Raman shift range varied from 200 to 1100 $\mathrm{cm}^{-1}$.

Transmission electron microscopy (TEM) images were recorded on a TecnaiTM F30 transmission electron microscope. STEM mapping images of some typical catalysts were also obtained by using the TecnaiTM F30 instrument that was equipped with an Oxford EDX detector operating at $300 \mathrm{keV}$.

$\mathrm{H}_{2}$ temperature-programmed reduction $\left(\mathrm{H}_{2}-\mathrm{TPR}\right)$ experiments were also carried out by using a FINESORB 3010C instrument. In general, $0.05 \mathrm{~g}$ of the catalysts was used for the tests. Before the experiments, the catalysts were pretreated in high-purity air that flowed at $120^{\circ} \mathrm{C}$ for $30 \mathrm{~min}$ to remove any possible surface impurities. After purging with ultrahigh purity argon that flowed at room temperature for $30 \mathrm{~min}$, the temperature was then increased from room temperature to $800^{\circ} \mathrm{C}$, with the ramp rate being $10{ }^{\circ} \mathrm{C} \mathrm{min}-1$, in $30 \mathrm{~mL} \mathrm{~min}^{-1} 10 \%$ $\mathrm{H}_{2}$ /Ar gas mixture flow. A thermal conductivity detector (TCD) was employed to monitor the $\mathrm{H}_{2}$ uptake. To quantify the amount of $\mathrm{H}_{2}$ consumed, a $99.99 \% \mathrm{CuO}$ sample was used as the calibration standard.

Temperature-programmed oxygen desorption ( $\mathrm{O}_{2}$-TPD) measurements were performed on a DAS-7000 multiple adsorption instrument that was equipped with a TCD detector. Typically, $0.05 \mathrm{~g}$ of the sample was placed in a quartz reactor, which was pretreated in $30 \mathrm{~mL} \mathrm{~min}^{-1}$ ultrahigh purity argon flow at $300^{\circ} \mathrm{C}$ for $60 \mathrm{~min}$. Afterwards, the sample was cooled to
$50{ }^{\circ} \mathrm{C}$ and saturated in a $10 \% \mathrm{O}_{2}+\mathrm{Ar}$ flow at the rate of $30 \mathrm{~mL}$ $\mathrm{min}^{-1}$, which was followed by flushing in $30 \mathrm{~mL} \mathrm{~min}^{-1}$ ultrahigh purity argon flow for $60 \mathrm{~min}$ to remove any physically adsorbed $\mathrm{O}_{2}$. The TPD experiments were then carried out from 50 to $700{ }^{\circ} \mathrm{C}$ at the heating rate of $10{ }^{\circ} \mathrm{C} \mathrm{min}^{-1}$ in $30 \mathrm{~mL} \mathrm{~min}^{-1} \mathrm{ul}-$ trahigh purity argon flow.

Soot temperature-programmed reduction (soot-TPR) experiments were conducted by using a TP-5076 multiple adsorption instrument (Xian-quan, China). Typically, $55 \mathrm{mg}$ of the sample, which was prepared by uniform mixing of $5 \mathrm{mg}$ soot with $50 \mathrm{mg}$ catalyst powder, was placed in a quartz reactor. Prior to the test, it was treated in ultrahigh purity argon flow for $60 \mathrm{~min}$ at $120^{\circ} \mathrm{C}$ to remove any physically adsorbed impurities. Afterwards, soot-TPR was carried out from 50 to $800{ }^{\circ} \mathrm{C}$ at the heating rate of $10{ }^{\circ} \mathrm{C} \mathrm{min}-1$ in $30 \mathrm{~mL} \mathrm{~min}^{-1}$ ultrahigh purity argon flow. A TCD was employed to monitor the formation of $\mathrm{CO}_{2}$.

\subsection{Activity evaluation}

Temperature-programmed oxidation (TPO) was used to evaluate the soot combustion activities of the catalysts. To determine the activity of a catalyst under tight contact condition, typically, $5 \mathrm{mg}$ of soot (Printex-U, diameter $25 \mathrm{~nm}$, purchased from Degussa) was mixed with $50 \mathrm{mg}$ of catalyst powder and ground for $10 \mathrm{~min}$. Before loading into a microreactor with an inner diameter of $6 \mathrm{~mm}$, the mixture was diluted by adding 100 $\mathrm{mg}$ of inert silica to ensure a soot/catalyst/silica weight ratio of $1 / 10 / 20$ to avoid the formation of hot spots during the activity test. A K-type thermocouple was used to accurately monitor the temperature of the catalyst bed, with the thermocouple head point touching the catalyst. To examine the reaction behaviors of the catalysts, all data were collected by increasing the temperature from 120 to $800{ }^{\circ} \mathrm{C}$ at the rate of $10^{\circ} \mathrm{C} \mathrm{min}-1$. The volume composition of the feed gas was $10 \% \mathrm{O}_{2}$, with the balance being high-purity argon; the flow rate was $30 \mathrm{~mL} \mathrm{~min}^{-1}$. To accurately quantify the amount of $\mathrm{O}_{2}$ consumed, prior to entering the TCD, the $\mathrm{CO}_{2}$ formed was removed thoroughly by using a soda-lime trap.

\section{Results and discussion}

\subsection{XRD analysis of the catalysts}

$\mathrm{XRD}$ was used to determine the phase compositions of the $\mathrm{CuO} / \mathrm{SnO}_{2}$ samples, and the patterns are shown in Fig. 1(A). For the pure $\mathrm{SnO}_{2}$ support, tetragonal rutile $\mathrm{SnO}_{2}$ is the only crystalline phase detected, as evidenced by the three typical diffraction peaks: $(110)=26.79^{\circ},(101)=34.12^{\circ}$, and $(211)=52.10^{\circ}$ (JCPDS no. 41-1445). For pure $\mathrm{CuO}$, monoclinic $\mathrm{CuO}$ is the only detected crystalline phase, as indicated by the three typical sharp peaks: $(11-1)=35.68^{\circ},(111)=38.95^{\circ}$, and $(20-2)=$ $49.04^{\circ}[27,30]$. For all the $\mathrm{CuO} / \mathrm{SnO}_{2}$ samples with different loadings, the rutile $\mathrm{SnO}_{2}$ phase is obviously detected with very similar peak intensities, proving that the addition of different amounts of $\mathrm{CuO}$ has no evident impact on the crystallinity of the $\mathrm{SnO}_{2}$ support. Interestingly, when the $\mathrm{CuO}$ loading is below 

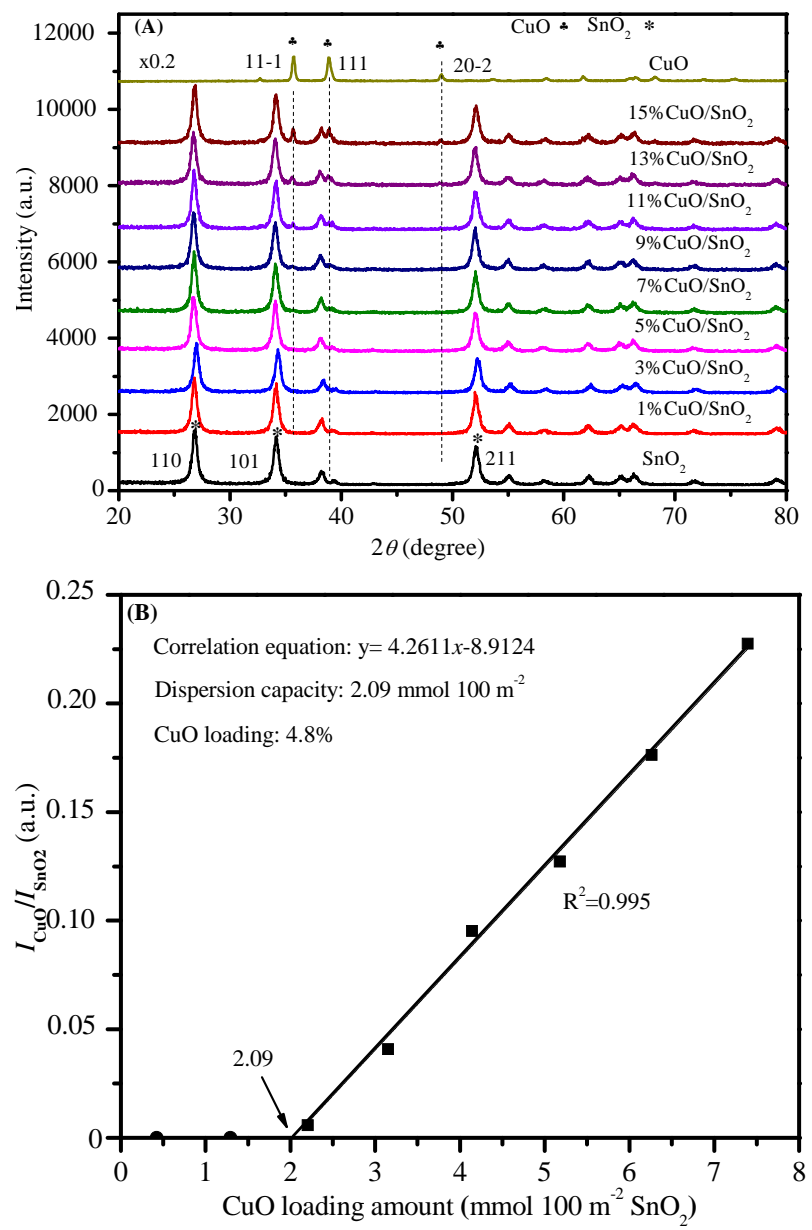

Fig. 1. XRD analysis of $\mathrm{CuO} / \mathrm{SnO}_{2}$ catalysts with different $\mathrm{CuO}$ loadings. (A) XRD patterns, and (B) the correlation line for quantifying the monolayer dispersion capacity of $\mathrm{CuO}$ on $\mathrm{SnO}_{2}$.

$5 \%$, no diffraction peak related to it can be observed, which indicates that $\mathrm{CuO}$ is dispersed finely on the support surface and is nearly amorphous. However, when the CuO loading is above $5 \%$, the monoclinic $\mathrm{CuO}$ phase starts to appear, the intensity of which increases with the increase in the CuO loading.

According to earlier studies, for a metal oxide dispersed on a support, there exists a monolayer dispersion capacity [9]. When the loading is not higher than this capacity, a sub-monolayer or monolayer of the supported metal oxide will be formed. On the other hand, when the loading is above this capacity, the excess supported metal oxide will start forming micro-crystallites, the average size of which increases with loading until the size reaches $5 \mathrm{~nm}$ and can be detected by XRD. Therefore, to determine the monolayer capacity accurately, the XRD extrapolation method was developed previously by Xie et al. [9,31]. Based on this method, the monolayer dispersion capacity of $\mathrm{CuO}$ on $\mathrm{SnO}_{2}$ support was correlated and quantified, as shown in Fig. 1(B). In detail, the intensity of the $\mathrm{CuO}$ (11-1) peak of each sample was measured and divided by the intensity of the $\mathrm{SnO}_{2}(110)$ peak to obtain a series of $I_{\mathrm{CuO}} / I_{\mathrm{SnO}}$ ratios, which are then plotted against the $\mathrm{CuO}$ loading to obtain a correlation line. The line intersects the $\mathrm{x}$-axis at a point, as displayed in Fig. 1(B). The CuO loading corresponding to this point is considered as the monolayer dispersion capacity of $\mathrm{CuO}$ on $\mathrm{SnO}_{2}$ support, which is $2.09 \mathrm{mmol} 100 \mathrm{~m}^{-2} \mathrm{SnO}_{2}$ surface. Upon conversion, this monolayer dispersion capacity equals $4.8 \mathrm{wt} \%$ loading.

\subsection{XPS analysis of the catalysts}

XPS technique was employed to evaluate the surface properties of some typical $\mathrm{CuO} / \mathrm{SnO}_{2}$ samples (Fig. 2). Fig. 2(A) presents the XPS spectra of the $\mathrm{SnO}_{2}$ support, which displays two $\mathrm{Sn} 3 d$ peaks at 487.2 and $495.6 \mathrm{eV}$ that are assigned to $\mathrm{Sn} 3 d_{5 / 2}$ and $3 d_{3 / 2}$ in that order [31]. In contrast, $\mathrm{CuO}$ reveals two typical $\mathrm{Cu} 2 p$ peaks at 934.2 and $953.0 \mathrm{eV}$, as displayed in Fig. 2(B), which are assigned to $\mathrm{Cu} 2 p_{3 / 2}$ and $2 p_{1 / 2}$ in that order [32]. In all the $\mathrm{CuO} / \mathrm{SnO}_{2}$ samples, the two typical $\mathrm{SnO}_{2}$ and $\mathrm{CuO}$ peaks can also be observed, but with some slight shifts. In comparison with the binding energies of pure $\mathrm{CuO}$ and $\mathrm{SnO}_{2}$, the binding energy of $\mathrm{CuO}$ in the $\mathrm{CuO} / \mathrm{SnO}_{2}$ samples increases, but that of $\mathrm{SnO}_{2}$ decreases, which indicates that the $\mathrm{CuO}$ present on the surface interacts with the $\mathrm{SnO}_{2}$ support and donates electrons to it.

With the increase in the CuO loading, the intensity of the Sn $3 d$ peak decreases, whereas that of the $\mathrm{Cu} 2 p$ peak increases, as observed in Fig. 2(A) and 2(B). Therefore, to further confirm the monolayer dispersion capacity of $\mathrm{CuO}$ on $\mathrm{SnO}_{2}$ support that was determined by XRD, the XPS extrapolation method was also used to measure the capacity [9]. In detail, the intensity of the $\mathrm{Cu} 2 p_{1 / 2}$ peak is divided by that of the $\mathrm{Sn} 3 d_{5 / 2}$ peak for each sample to obtain a series of $I_{\mathrm{Sn} 3 d} / I_{\mathrm{Cu} 2 p}$, which are then plotted against the $\mathrm{CuO}$ loadings of the samples. As exhibited in Fig. 2(C), two linearly correlated lines with different slopes are
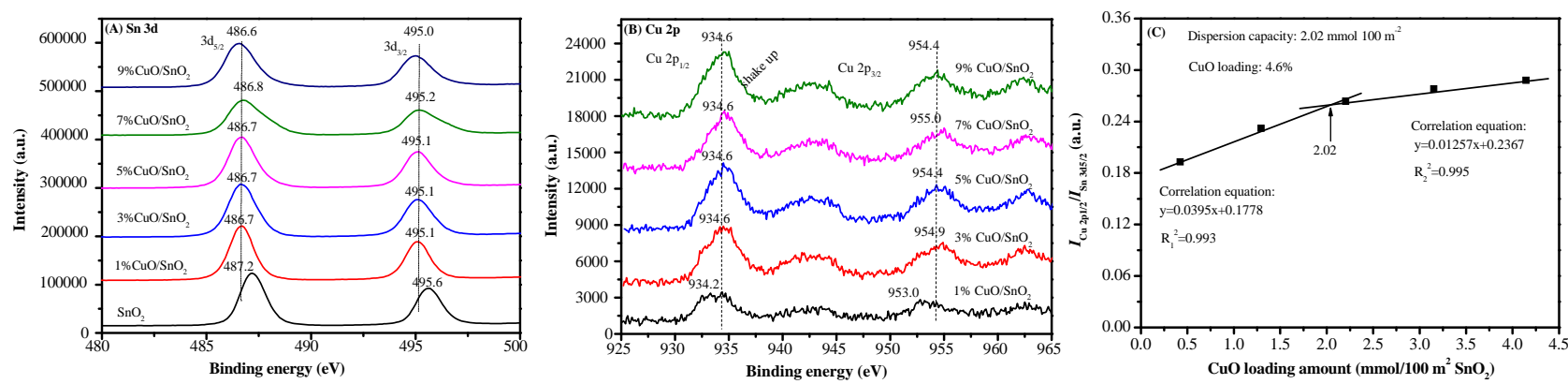

Fig. 2. XPS analysis of $\mathrm{CuO} / \mathrm{SnO}_{2}$ catalysts with different $\mathrm{CuO}$ loadings. (A) $\mathrm{Sn} 3 d$; (B) $\mathrm{Cu} 2 p$; (C) the monolayer dispersion capacity of $\mathrm{CuO}_{2}$ on $\mathrm{SnO}_{2}$ support, as quantified by XPS extrapolation. 

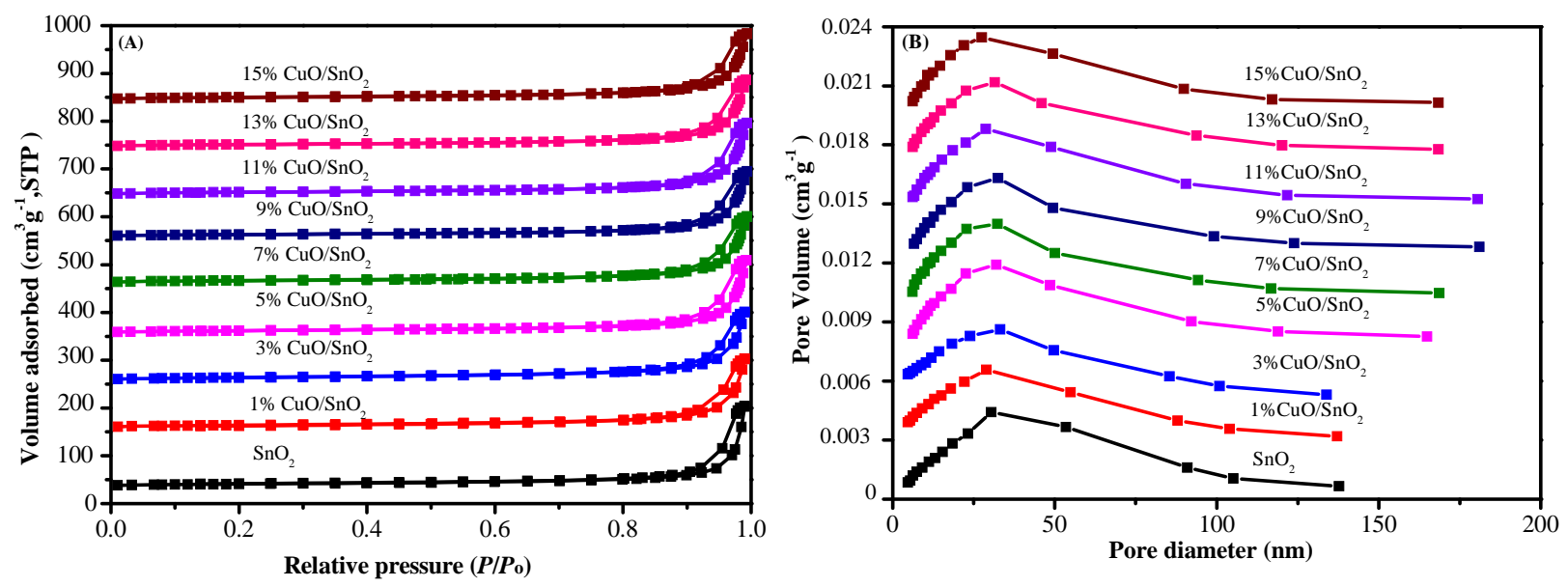

Fig. 3. $\mathrm{N}_{2}$ adsorption-desorption study of $\mathrm{CuO} / \mathrm{SnO}_{2}$ catalysts with different $\mathrm{CuO}$ loadings. (A) isotherms; (B) pore size distribution profiles.

obtained, which intersect each other at the point corresponding to $2.02 \mathrm{mmol} 100 \mathrm{~m}^{-2} \mathrm{SnO}_{2}$. According to previous studies [9], the $\mathrm{CuO}$ loading corresponding to this point corresponds to the monolayer dispersion capacity of $\mathrm{CuO}$ on $\mathrm{SnO}_{2}$. Within the experimental error range, this value is the same as that of 2.09 mmol $100 \mathrm{~m}^{-2} \mathrm{SnO}_{2}$, which is the monolayer dispersion capacity obtained by the XRD extrapolation method.

In brief, the results obtained by using the XRD and XPS extrapolation methods are highly consistent with each other, testifying that $\mathrm{CuO}$ exhibits a monolayer dispersion capacity of around $2.09 \mathrm{mmol} 100 \mathrm{~m}^{-2}$ on $\mathrm{SnO}_{2}$ support, which equals 4.8 $\mathrm{wt} \% \mathrm{CuO}$ loading. Above this capacity, the excess $\mathrm{CuO}$ starts to form $\mathrm{CuO}$ micro-crystallites, the average grain sizes of which increase until they are detectable by XRD.

\section{3. $\mathrm{N}_{2}$ adsorption-desorption measurements of the catalysts}

The texture properties of the catalysts were evaluated through $\mathrm{N}_{2}$ adsorption-desorption experiments, and the results are shown in Fig. 3. It is noted here that with the increase in the $\mathrm{CuO}$ loading, the surface areas of the $\mathrm{CuO} / \mathrm{SnO}_{2}$ samples decrease slightly, as observed in Table 1 . For all the samples containing the $\mathrm{SnO}_{2}$ support, Fig. 3(A) indicates that a type IV

Table 1

Physicochemical properties of $\mathrm{CuO} / \mathrm{SnO}_{2}$ catalysts with different $\mathrm{CuO}$ loadings.

\begin{tabular}{lcc}
\hline Sample & $\begin{array}{c}\text { Average crystallite size } \\
(\mathrm{nm})\end{array}$ & $\begin{array}{c}\text { Surface } \text { area }^{\mathrm{b}} \\
\left(\mathrm{m}^{2} \mathrm{~g}^{-1}\right)\end{array}$ \\
\hline $\mathrm{SnO}_{2}$ & 13.3 & 32 \\
$1 \% \mathrm{CuO} / \mathrm{SnO}_{2}$ & 13.6 & 31 \\
$3 \% \mathrm{CuO} / \mathrm{SnO}_{2}$ & 12.8 & 32 \\
$5 \% \mathrm{CuO} / \mathrm{SnO}_{2}$ & 13.4 & 30 \\
$7 \% \mathrm{CuO} / \mathrm{SnO}_{2}$ & 13.7 & 31 \\
$9 \% \mathrm{CuO} / \mathrm{SnO}_{2}$ & 12.9 & 27 \\
$11 \% \mathrm{CuO} / \mathrm{SnO}_{2}$ & 13.7 & 28 \\
$13 \% \mathrm{CuO} / \mathrm{SnO}_{2}$ & 13.3 & 26 \\
$15 \% \mathrm{CuO} / \mathrm{SnO}_{2}$ & 13.3 & 27 \\
\hline
\end{tabular}

${ }^{a}$ Calculated by Scherrer's equation for the (110) peak.

b Calculated by the BET method. isotherm and an H3-type hysteresis loop in the relative pressure $\left(P / P_{0}\right)$ range $0.8-1.0$ are observed. Fig. $3(\mathrm{~B})$ reveals that the pore size distribution profiles of the samples are similar upon changing the $\mathrm{CuO}$ loading, proving that $\mathrm{CuO}$ is dispersed finely on the $\mathrm{SnO}_{2}$ support, without any evident impact on its texture properties.

\subsection{TEM, HR-TEM, and STEM mapping studies of the catalysts}

As quantified by the XRD and XPS extrapolation methods, the monolayer dispersion capacity of $\mathrm{CuO}$ on $\mathrm{SnO}_{2}$ support is $2.09 \mathrm{mmol} 100 \mathrm{~m}^{-2}$, which equals a $\mathrm{CuO}$ loading of $4.8 \%$. Therefore, to investigate the changes in the surface properties of the $\mathrm{CuO} / \mathrm{SnO}_{2}$ samples by altering the $\mathrm{CuO}$ loading, three typical catalysts with $\mathrm{CuO}$ loadings below (1\%), close to (5\%), and above $(9 \%)$ the monolayer dispersion capacity were analyzed by TEM. Fig. 4(A, C, and E) reveals that all the three samples are composed of irregular spherical particles, indicating that the change in the CuO loading has no evident impact on the morphology.

Interestingly, the HR-TEM image of $1 \% \mathrm{CuO} / \mathrm{SnO}_{2}$ in Fig. 4(B) shows only the (101) and (110) diffraction planes of the $\mathrm{SnO}_{2}$ support. None of the $\mathrm{CuO}$ diffraction peaks are observed, which testify the fact that below the monolayer capacity, $\mathrm{CuO}$ is present on the surface in an amorphous state. However, in Fig. 4(D) and (F), which display the HR-TEM images of $5 \%$ $\mathrm{CuO} / \mathrm{SnO}_{2}$ and $9 \% \mathrm{CuO} / \mathrm{SnO}_{2}$, besides the diffraction planes of $\mathrm{SnO}_{2}$, the $\mathrm{Cu}$ (11-1) plane of crystalline $\mathrm{CuO}$ is obviously detected, with the planar distance being $0.260 \mathrm{~nm}$. This demonstrates that when the $\mathrm{CuO}$ loading is above the monolayer dispersion capacity, the excess $\mathrm{CuO}$ forms micro-crystallites on top of the $\mathrm{CuO}$ monolayer.

To obtain more direct information on the $\mathrm{CuO}$ dispersion, the three typical samples were further studied by STEM mapping, and the images are exhibited in Fig. 5. For $1 \% \mathrm{CuO} / \mathrm{SnO}_{2}$, elemental copper is distributed highly homogeneously along with elemental tin and oxygen, suggesting that it is dispersed very finely on the $\mathrm{SnO}_{2}$ support surface. However, in the mapping images of $5 \% \mathrm{CuO} / \mathrm{SnO}_{2}$, some local $\mathrm{CuO}$ aggregation is 

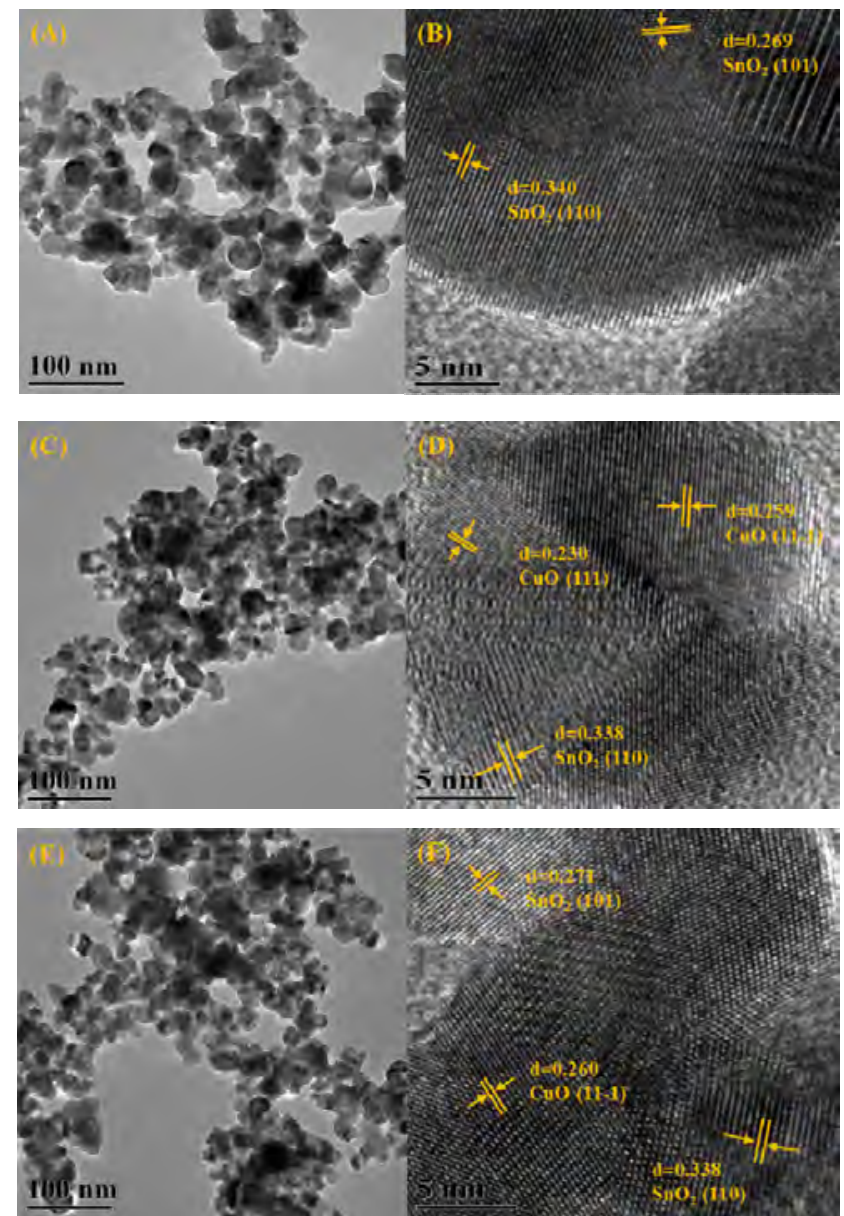

Fig. 4. TEM and HR-TEM images of $\mathrm{CuO} / \mathrm{SnO}_{2}$ catalysts. (A, B) $1 \%$; (C, D) 5\%; (E, F) 9\%.

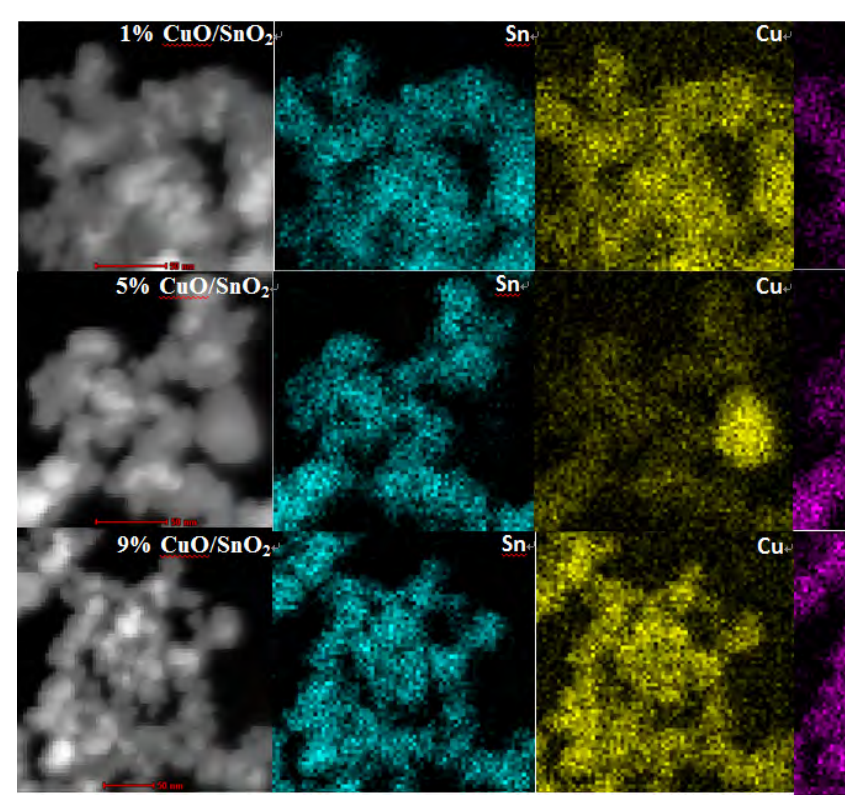

Fig. 5. STEM mapping images of $1 \% \mathrm{CuO} / \mathrm{SnO}_{2}, 5 \% \mathrm{CuO} / \mathrm{SnO}_{2}$, and $9 \%$ $\mathrm{CuO} / \mathrm{SnO}_{2}$ catalysts.

evidently observed, as indicated by the randomly bright copper mapping spot, which is not accompanied by any elemental tin. This indicates that some excess $\mathrm{CuO}$ has already formed in the micro-crystallites. In contrast, in the images of $9 \% \mathrm{CuO} / \mathrm{SnO}_{2}$, owing to the formation of a much larger amount of $\mathrm{CuO}$ micro-crystallites, the copper mapping signal becomes completely bright, with some of the copper species not being accompanied by elemental tin.

In summary, both the HR-TEM and STEM mapping results reveal that when the $\mathrm{CuO}$ loading is below the monolayer dispersion capacity, $\mathrm{CuO}$ is present in an amorphous monolayer dispersed state on the support surface. On the other hand, if the $\mathrm{CuO}$ loading is above the capacity, crystalline $\mathrm{CuO}$ particles will then be formed. These microscopy results provide direct evidence that confirm what was observed through XRD and XPS.

\subsection{Raman characterization of the catalysts}

The surface properties of the $\mathrm{CuO} / \mathrm{SnO}_{2}$ samples were further analyzed by Raman spectroscopy in the shift range $200-1100 \mathrm{~cm}^{-1}$, and the results are displayed in Fig. 6. For comparison purpose, the Raman spectra of pure $\mathrm{CuO}$ and $\mathrm{SnO}_{2}$ support were also collected. Monoclinic $\mathrm{CuO}$ displays three typical Raman bands, which are $\mathrm{Ag}_{\mathrm{g}}$ at $275 \mathrm{~cm}^{-1}$ and $\mathrm{Bg}$ at 320 and $605 \mathrm{~cm}^{-1}[27,33]$. The $\mathrm{CVD}^{\mathrm{SnO}}{ }_{2}$ support used in this study exhibits tetragonal rutile structure, which belongs to the D144h space group. According to group theory, its active Raman modes are $B_{1 g}, E_{g}, A_{1 g}$, and $B_{2 g}$, and theoretically four first-order Raman peaks should be observed [34]. However, as shown in Fig. 6, only three Raman peaks at 478, 636, and $780 \mathrm{~cm}^{-1}$, corresponding to the $\mathrm{E}_{\mathrm{g}}, \mathrm{A}_{1 \mathrm{~g}}$, and $\mathrm{B}_{2 \mathrm{~g}}$ vibration modes, respectively, are detected.

For the $\mathrm{CuO} / \mathrm{SnO}_{2}$ samples, when the $\mathrm{CuO}$ loading is below $5 \%$, the three typical Raman peaks of rutile $\mathrm{SnO}_{2}$ are still evidently observed, but their intensities decrease with the increase in the $\mathrm{CuO}$ loading. In addition, the $\mathrm{A}_{1 \mathrm{~g}}$ and $\mathrm{B}_{2 \mathrm{~g}}$ bands shift to lower values gradually, which suggest interaction between $\mathrm{CuO}$ and $\mathrm{SnO}_{2}$ support. In comparison, when the $\mathrm{CuO}$ loading is above the monolayer dispersion capacity and reaches $7 \%$, it seems that the Eg band of rutile $\mathrm{SnO}_{2}$ shifts to $498 \mathrm{~cm}^{-1}$, while the $A_{1 g}$ and $B_{2 g}$ bands shift further to lower values. More interestingly, two new Raman peaks at about $541 \mathrm{~cm}^{-1}\left(\mathrm{~A}_{1}\right)$ and $684 \mathrm{~cm}^{-1}\left(\mathrm{~A}_{2}\right)$ are also observed in the spectra of the $\mathrm{CuO} / \mathrm{SnO}_{2}$

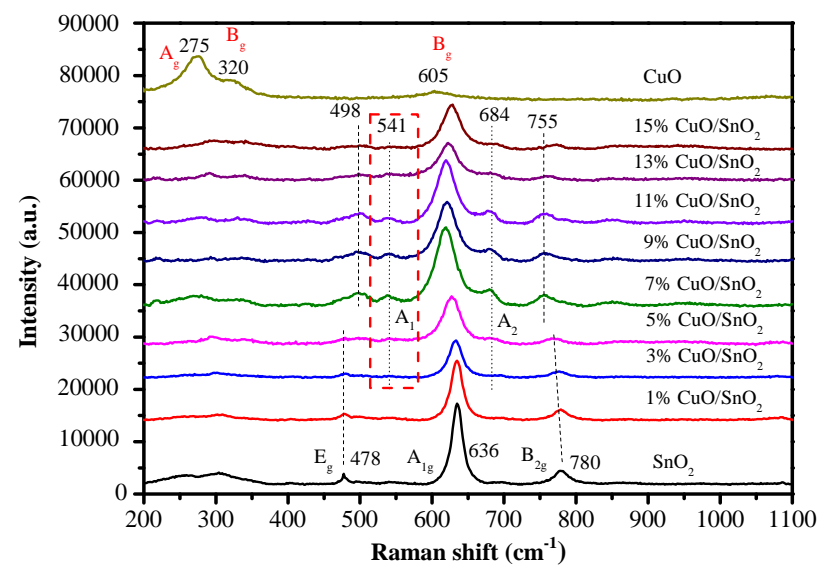

Fig. 6. Raman spectra of $\mathrm{CuO} / \mathrm{SnO}_{2}$ catalysts with different $\mathrm{CuO}$ loadings. 
samples. According to the literature [34-36], the former peak is ascribed to the interface or surface phonon modes, and corresponds to surface defects such as oxygen vacancies and lattice disorder. The latter peak is believed to correspond to the IR-active A2uLO modes. It is apparent that the difference in the $\mathrm{CuO}$ loading has altered the surface properties of the $\mathrm{SnO}_{2}$ support. Particularly, for the sample with $\mathrm{CuO}$ loading close to the monolayer dispersion capacity, an abrupt change in the surface property can be observed. The presence of this turning point indicates that the interactions of monolayer $\mathrm{CuO}$ and crystalline $\mathrm{CuO}$ with $\mathrm{SnO}_{2}$ support are different, which testify to the presence of a threshold effect on the surface composition. Indeed, the Raman results are highly consistent with the XRD and XPS results, proving that $\mathrm{CuO}$ exhibits a monolayer dispersion capacity of $2.09 \mathrm{mmol} 100 \mathrm{~m}^{-2}$, which equals a CuO loading of around $4.8 \%$.

\subsection{Evaluation of the soot combustion activity}

Soot combustion was used to investigate the reaction performances of the $\mathrm{CuO} / \mathrm{SnO}_{2}$ catalysts, with the TPO profiles depicted in Fig. 7. For easy comparison, the $T_{\mathrm{i}}, T_{\mathrm{p}}$, and $\Delta T_{\mathrm{i}-\mathrm{p}}$, which are the combustion ignition temperature, peak temperature, and the gap between the two temperatures, respectively, are listed in Table 2. For the thermal combustion of pure soot without any catalyst, the $T_{\mathrm{i}}$ and $T_{\mathrm{p}}$ are 530 and $630^{\circ} \mathrm{C}$, respectively, and the $\Delta T_{\mathrm{i}-\mathrm{p}}$ is as wide as $100^{\circ} \mathrm{C}$. With the incorporation of $\mathrm{CVD} \mathrm{SnO}_{2}$ as the catalyst, the $T_{\mathrm{i}}$ and $T_{\mathrm{p}}$ drop slightly to 525 and $605{ }^{\circ} \mathrm{C}$, respectively, and the $\Delta T_{\mathrm{i} \text {-p }}$ becomes $20^{\circ} \mathrm{C}$ narrower, indicating that the presence of $\mathrm{SnO}_{2}$ accelerates the combustion process. Interestingly, with the addition of even $1 \% \mathrm{CuO}$, the $T_{\mathrm{i}}$ and $T_{\mathrm{p}}$ drop significantly to 505 and $560{ }^{\circ} \mathrm{C}$, respectively, and the $\Delta T_{\mathrm{i} \text {-p }}$ becomes $55^{\circ} \mathrm{C}$, which strongly suggest that the presence of dispersed surface $\mathrm{CuO}$ has a tremendous influence on the activity. By increasing the $\mathrm{CuO}$ loading to $5 \%$, which is close to the monolayer loading of $4.8 \%$, the $T_{\mathrm{i}}$ and $T_{\mathrm{p}}$ drop further to 465 and $515{ }^{\circ} \mathrm{C}$, respectively, and the $\Delta T_{\mathrm{i}-\mathrm{p}}$ becomes $50{ }^{\circ} \mathrm{C}$. However, upon further increasing the $\mathrm{CuO}$ loading to $7 \%$ or higher, no significant impact on the reaction performance of the catalyst is observed. Starting from $5 \% \mathrm{CuO} / \mathrm{SnO}_{2}$, the sample

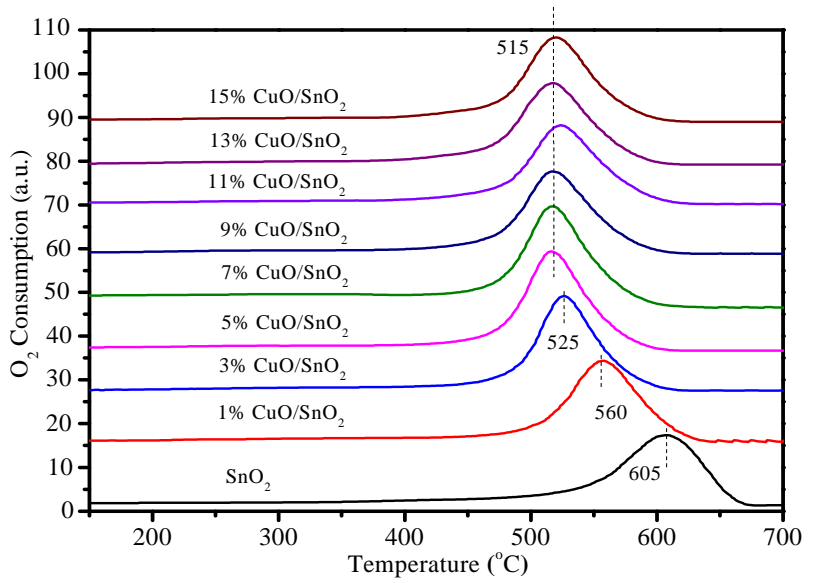

Fig. 7. Soot combustion over $\mathrm{CuO} / \mathrm{SnO}_{2}$ catalysts with different $\mathrm{CuO}$ loadings.
Table 2

Soot combustion on $\mathrm{CuO} / \mathrm{SnO}_{2}$ catalysts with different $\mathrm{CuO}$ loadings.

\begin{tabular}{lccc}
\hline Catalyst & $T_{\mathrm{i}}\left({ }^{\circ} \mathrm{C}\right)$ & $T_{\mathrm{p}}\left({ }^{\circ} \mathrm{C}\right)$ & $\Delta T_{\mathrm{i}-\mathrm{p}}\left({ }^{\circ} \mathrm{C}\right)$ \\
\hline Blank & 530 & 630 & 100 \\
$\mathrm{SnO}_{2}$ & 525 & 605 & 80 \\
$1 \% \mathrm{CuO} / \mathrm{SnO}_{2}$ & 505 & 560 & 55 \\
$3 \% \mathrm{CuO} / \mathrm{SnO}_{2}$ & 480 & 525 & 45 \\
$5 \% \mathrm{CuO} / \mathrm{SnO}_{2}$ & 465 & 515 & 50 \\
$7 \% \mathrm{CuO} / \mathrm{SnO}_{2}$ & 470 & 515 & 45 \\
$9 \% \mathrm{CuO} / \mathrm{SnO}_{2}$ & 470 & 515 & 45 \\
$11 \% \mathrm{CuO} / \mathrm{SnO}_{2}$ & 470 & 515 & 45 \\
$13 \% \mathrm{CuO} / \mathrm{SnO}_{2}$ & 470 & 515 & 45 \\
$15 \% \mathrm{CuO} / \mathrm{SnO}_{2}$ & 470 & 515 & 45 \\
\hline
\end{tabular}

with a loading close to the monolayer dispersion capacity, all the catalysts with higher $\mathrm{CuO}$ loadings exhibit nearly the same activity relative to each other, which proves that beyond the monolayer capacity, increasing the $\mathrm{CuO}$ loading does not have a beneficial effect on the soot combustion activity. Apparently, this substantiates the fact that the $\mathrm{CuO}$ monolayer on $\mathrm{SnO}_{2}$ support plays a crucial role in determining the reactivity of the catalyst. In addition, the presence of the turning point suggests a strong threshold effect for the $\mathrm{CuO} / \mathrm{SnO}_{2}$ catalysts for the soot combustion activity.

Soot combustion over $\mathrm{CuO} / \mathrm{SnO}_{2}$ catalysts should follow the Mars-van Krevlen mechanism, which involves the consumption and regeneration of surface-active oxygen species [36]. With the addition of $\mathrm{CuO}$, active surface oxygen species is formed, as evidenced by the Raman results, which is possibly related to the formation of $\mathrm{Cu}-\mathrm{O}-\mathrm{Sn}$ interface bonds. Many earlier studies have demonstrated that for supported metal oxide systems, surface interface bonds can be effectively generated, and that the interfacial oxygen species are active and selective towards many oxidation reactions $[37,38]$. In this study, although the $\mathrm{Cu}-\mathrm{O}-\mathrm{Sn}$ interface bonds were not directly observed, the Raman results in Fig. 6 prove the interaction between $\mathrm{CuO}$ and $\mathrm{SnO}_{2}$ support, which induces the formation of surface-active oxygen species. In the following sections, more experimental details will be provided to support this theory.

Below the monolayer dispersion capacity, $\mathrm{CuO}$ keeps the $\mathrm{SnO}_{2}$ support surface covered, thus producing more $\mathrm{Cu}-\mathrm{O}-\mathrm{Sn}$ interface bonds and improving the activity continuously. On the other hand, above the monolayer dispersion capacity, the excess $\mathrm{CuO}$ starts to form micro-crystallites, which remain on top of the $\mathrm{CuO}$ monolayer. Since crystalline $\mathrm{CuO}$ itself is very active towards oxidation reactions [19,20,27,39], the activities of the catalysts with $\mathrm{CuO}$ loadings above the monolayer capacity are not degraded by the formation of $\mathrm{CuO}$ crystallites, but rather retained without any evident change.

The stability of a soot combustion catalyst determines its potential for application. Therefore, the typical $5 \% \mathrm{CuO} / \mathrm{SnO}_{2}$ catalyst was subjected to five continuous TPO tests. As illustrated in Fig. 8, no temperature increase is observed after five cycles, which indicates that the catalyst displays stable reaction performance and has potential for application in some real exhaust post-treatment processes. 


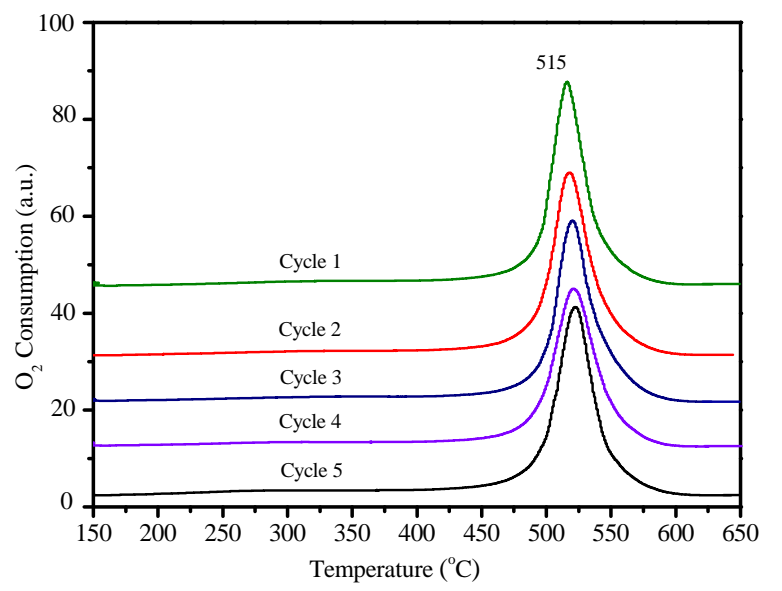

Fig. 8. Stability test of $5 \% \mathrm{CuO} / \mathrm{SnO}_{2}$ for soot combustion over five continuous TPO cycles.

\section{7. $\mathrm{H}_{2}$-TPR studies of the catalysts}

$\mathrm{H}_{2}$-TPR experiments were performed to evaluate the redox properties of the $\mathrm{CuO} / \mathrm{SnO}_{2}$ catalysts, and the profiles are presented in Fig. 9. Pure $\mathrm{SnO}_{2}$ shows a major reduction peak at 660 ${ }^{\circ} \mathrm{C}$, which is assigned to the reduction of bulk $\mathrm{SnO}_{2}$ to metallic tin $[24,40]$; this is also verified by the quantification results shown in Table 3. For all the $\mathrm{CuO} / \mathrm{SnO}_{2}$ samples, besides the major reduction peak of $\mathrm{SnO}_{2}$, a group of low-temperature reduction peaks assigned to $\mathrm{CuO}$ reduction are observed [27], which is confirmed by the quantified $\mathrm{O} / \mathrm{Cu}$ atomic ratios listed in Table 3. For the reduction of bare $\mathrm{CuO}$, two peaks are typically observed in the range 200 to $400{ }^{\circ} \mathrm{C}$, which are attributed to the stepwise reduction of $\mathrm{CuO}$ to $\mathrm{Cu}_{2} \mathrm{O}$ and eventually to metallic copper [24]. It is apparent that in all the $\mathrm{CuO} / \mathrm{SnO}_{2}$ samples, the reduction of $\mathrm{CuO}$ shifts to a significantly lower temperature region (below $300{ }^{\circ} \mathrm{C}$ ), due to the fine dispersion of $\mathrm{CuO}$ on the support surface. As demonstrated earlier, when a metal oxide disperses finely on a support surface, its reduction will become thermodynamically favorable $[9,11]$. However, even in the sub-monolayer or monolayer dispersed state, two peaks corresponding to the two typical reduction steps of $\mathrm{CuO}$

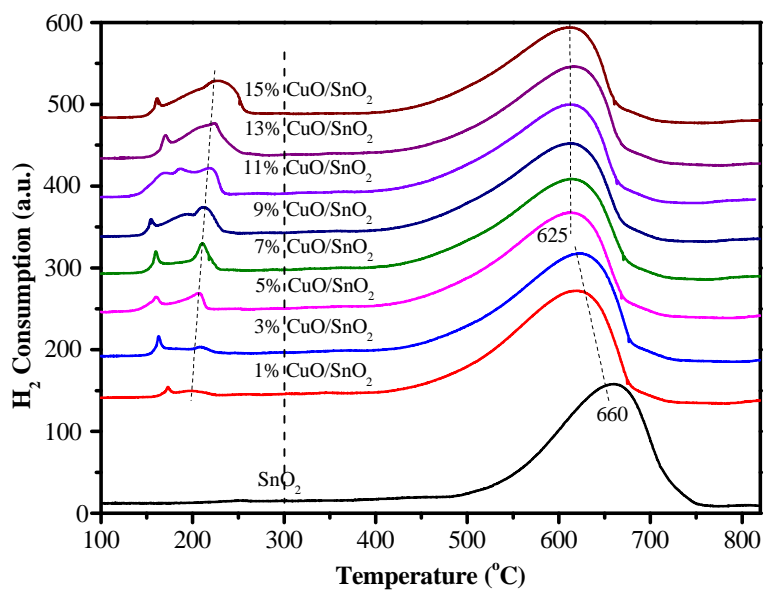

Fig. 9. $\mathrm{H}_{2}$-TPR profiles of $\mathrm{CuO} / \mathrm{SnO}_{2}$ catalysts with different $\mathrm{CuO}$ loadings.
Table 3

Quantified $\mathrm{H}_{2}$-TPR results of $\mathrm{CuO} / \mathrm{SnO}_{2}$ catalysts with different $\mathrm{CuO}$ loadings.

\begin{tabular}{lcccc}
\hline Catalyst & $\begin{array}{c}\mathrm{H}_{2} \text { uptake amount } \\
\text { below } 300{ }^{\circ} \mathrm{C} \\
\left(\mathrm{mmol} \mathrm{g}^{-1} \mathrm{CuO}\right)\end{array}$ & $\begin{array}{c}\mathrm{O} / \mathrm{Cu} \\
\text { atomic } \\
\text { ratio }\end{array}$ & $\begin{array}{c}\mathrm{H}_{2} \text { uptake amount } \\
\text { above } 300{ }^{\circ} \mathrm{C} \\
\left(\mathrm{mmol} \mathrm{g}^{-1} \mathrm{SnO}_{2}\right)\end{array}$ & $\begin{array}{c}\mathrm{O} / \mathrm{Sn} \\
\text { atomic } \\
\text { ratio }\end{array}$ \\
\hline $\mathrm{SnO}_{2}$ & 0 & 0 & 13.3 & 2.0 \\
$1 \% \mathrm{CuO} / \mathrm{SnO}_{2}$ & 12.7 & 1.0 & 13.2 & 2.0 \\
$3 \% \mathrm{CuO} / \mathrm{SnO}_{2}$ & 12.9 & 1.0 & 13.3 & 2.0 \\
$5 \% \mathrm{CuO} / \mathrm{SnO}_{2}$ & 13.5 & 1.1 & 13.2 & 2.0 \\
$7 \% \mathrm{CuO} / \mathrm{SnO}_{2}$ & 13.7 & 1.1 & 13.3 & 2.0 \\
$9 \% \mathrm{CuO} / \mathrm{SnO}_{2}$ & 14.0 & 1.1 & 13.3 & 2.0 \\
$11 \% \mathrm{CuO} / \mathrm{SnO}_{2}$ & 13.7 & 1.1 & 13.2 & 2.0 \\
$13 \% \mathrm{CuO} / \mathrm{SnO}_{2}$ & 13.4 & 1.1 & 13.3 & 2.0 \\
$15 \% \mathrm{CuO} / \mathrm{SnO}_{2}$ & 13.3 & 1.1 & 13.1 & 2.0 \\
\hline
\end{tabular}

can still be clearly observed. With the increase in the $\mathrm{CuO}$ loading, the second peak around $200{ }^{\circ} \mathrm{C}$ becomes gradually larger, which confirms the formation of crystalline $\mathrm{CuO}$.

What is interesting here is the shift in the $\mathrm{SnO}_{2}$ reduction peak with the addition of $\mathrm{CuO}$. Below the monolayer dispersion capacity, with the increase in the $\mathrm{CuO}$ loading up to $5 \%$, the $\mathrm{SnO}_{2}$ reduction peak temperature drops from 660 to $625{ }^{\circ} \mathrm{C}$. However, further increasing the $\mathrm{CuO}$ loading to $15 \%$ results in the reduction peak temperature remaining at $625{ }^{\circ} \mathrm{C}$. This trend is highly consistent with the reaction performances of the catalysts. Therefore, it is believed that in the presence of gas-phase oxygen, the lattice oxygen of $\mathrm{SnO}_{2}$ could also be involved in the soot combustion process.

\section{8. $\mathrm{O}_{2}$-TPD and XPS studies on the oxygen properties of the catalysts}

To further understand the oxygen properties of the $\mathrm{CuO} / \mathrm{SnO}_{2}$ samples, $\mathrm{O}_{2}$-TPD experiments were performed, with the results shown in Fig. 10. For all the samples, two oxygen desorption peaks are observed around 110 and $580^{\circ} \mathrm{C}$. For the convenience of discussion, the desorption peak around $110^{\circ} \mathrm{C}$ is named $\alpha$ peak, whereas the desorption peak around $580^{\circ} \mathrm{C}$ is named $\beta$ peak. The $\alpha$ peak is assigned to the desorption of loosely bonded surface oxygens, whereas the $\beta$ peak is assigned

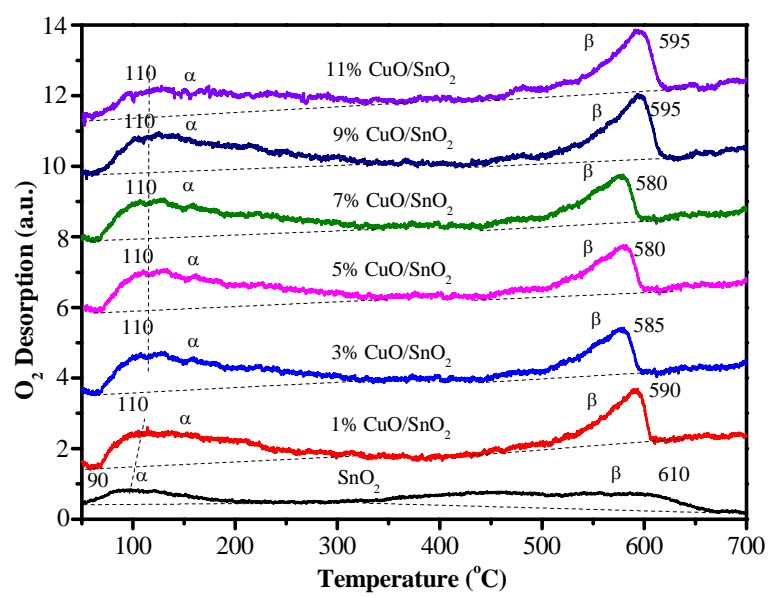

Fig. 10. $\mathrm{O}_{2}$-TPD profiles of $\mathrm{CuO} / \mathrm{SnO}_{2}$ catalysts with different $\mathrm{CuO}$ loadings. 
Table 4

Quantified $\mathrm{O}_{2}$-TPD results of catalysts with different $\mathrm{CuO}$ loadings.

\begin{tabular}{lccc}
\hline Catalyst & $\begin{array}{c}\text { Relative oxygen } \\
\text { amount of the } \\
\alpha \text { peak (a.u.) }\end{array}$ & $\begin{array}{c}\text { Relative oxygen } \\
\text { amount of the } \\
\beta \text { peak (a.u.) }\end{array}$ & $\begin{array}{c}\text { Total } \\
\text { (a.u.) }\end{array}$ \\
\hline $\mathrm{SnO}_{2}$ & 10 & 41 & 51 \\
$1 \% \mathrm{CuO} / \mathrm{SnO}_{2}$ & 50 & 35 & 85 \\
$3 \% \mathrm{CuO} / \mathrm{SnO}_{2}$ & 53 & 31 & 84 \\
$5 \% \mathrm{CuO} / \mathrm{SnO}_{2}$ & 58 & 32 & 90 \\
$7 \% \mathrm{CuO} / \mathrm{SnO}_{2}$ & 55 & 30 & 85 \\
$9 \% \mathrm{CuO} / \mathrm{SnO}_{2}$ & 53 & 37 & 90 \\
$11 \% \mathrm{CuO} / \mathrm{SnO}_{2}$ & 46 & 33 & 79 \\
\hline
\end{tabular}

to the desorption of mobile surface lattice oxygens [41]. For clarity of information, the integrated areas of the two peaks of each sample have been quantified and included in Table 4. With the addition of $\mathrm{CuO}$, the amount of loosely bonded surface oxygen increases significantly, proving again the generation of surface-active oxygen species due to the interaction between the dispersed $\mathrm{CuO}$ and the $\mathrm{SnO}_{2}$ support, which is evidenced by the Raman results. Although pure $\mathrm{SnO}_{2}$ contains a slightly larger amount of surface lattice oxygen than the $\mathrm{CuO} / \mathrm{SnO}_{2}$ samples, its peak is much wider in comparison with the $\beta$ peak of the $\mathrm{CuO} / \mathrm{SnO}_{2}$ catalysts, indicating the surface lattice oxygen of pure $\mathrm{SnO}_{2}$ is kinetically much less active than that of $\mathrm{CuO} / \mathrm{SnO}_{2}$. Furthermore, with the increase in the $\mathrm{CuO}$ loading from $1 \%$ to $7 \%$, the $\beta$ peak temperature decreases, indicating that when the $\mathrm{CuO}$ loading is close to the monolayer dispersion capacity, the most active surface lattice oxygen species can be formed. Upon further increasing the $\mathrm{CuO}$ loading, the $\beta$ peak temperature increases slightly due to the formation of surface $\mathrm{CuO}$ micro-crystallites. It is noted that the total oxygen desorption amounts of the $\mathrm{CuO} / \mathrm{SnO}_{2}$ catalysts are obviously higher than that of pure $\mathrm{SnO}_{2}$ support. Indeed, the presence of highly abundant and reactive surface oxygen species on $\mathrm{CuO} / \mathrm{SnO}_{2}$ could account for its much-improved soot combustion activity in comparison with that of pure $\mathrm{SnO}_{2}$.

To verify what is observed through $\mathrm{O}_{2}$-TPD experiments, some of the typical $\mathrm{CuO} / \mathrm{SnO}_{2}$ samples were also analyzed by XPS, with attention particularly paid to the surface oxygen property. As shown in Fig. 11, doublet $01 s$ peaks are observed for all the samples, suggesting the presence of two types of oxygen species with different chemical environments on the catalyst surfaces. According to the literature [42], the peak around $530.6 \mathrm{eV}$ is assigned to the surface lattice oxygen species, and the peak around $531.9 \mathrm{eV}$ can be ascribed to the loosely bounded surface oxygen species. For clarity, the per-
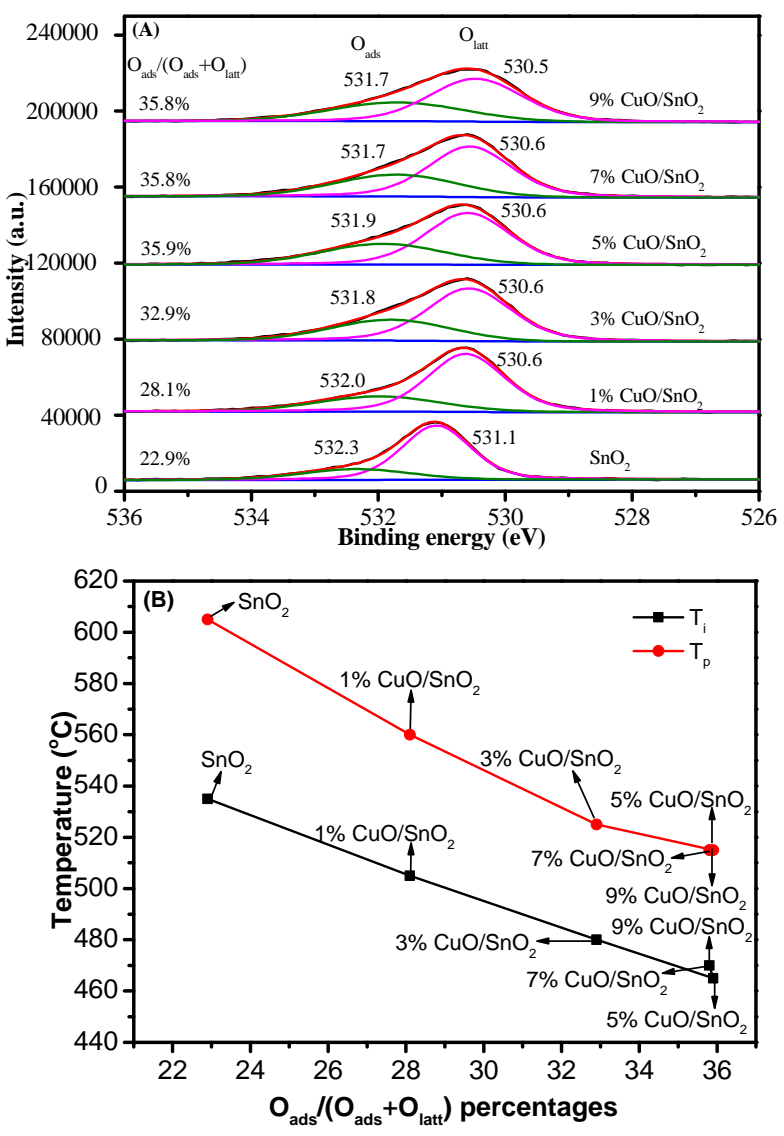

Fig. 11. XPS analysis of the $01 s$ peaks of $\mathrm{CuO} / \mathrm{SnO}_{2}$ catalysts with different CuO loadings. (A) $01 s$ spectra; (B) $T_{\mathrm{i}}, T_{\mathrm{p}}$ versus $\left(\mathrm{O}_{\text {ads }} /\left(\mathrm{O}_{\text {ads }}+\mathrm{O}_{\text {latt }}\right)\right.$ percentages.

centages of the surface loosely bounded oxygen species, $\mathrm{O}_{\text {ads }} /\left(\mathrm{O}_{\text {ads }}+\mathrm{O}_{\text {latt }}\right)$, are quantified and listed in Table 5 . With the addition of $1 \% \mathrm{CuO}$, the percentage increases from $22.9 \%$ to $28.1 \%$, testifying again that the interaction between the surface sub-monolayer $\mathrm{CuO}$ and the $\mathrm{SnO}_{2}$ support creates more abundant surface-active oxygen species. With the increase in the $\mathrm{CuO}$ loading to $5 \%$, the percentage improves to $35.9 \%$. However, further improving the $\mathrm{CuO}$ loading has little influence on the percentages of the loosely bounded surface oxygen species, which is in good accordance with the changes in the soot combustion activities of the catalysts.

To determine the relationship between the soot combustion activity and the amount of loosely bounded surface-active oxygen species, the $T_{\mathrm{i}}$ and $T_{\mathrm{p}}$ for soot combustion over the $\mathrm{CuO} / \mathrm{SnO}_{2}$ samples are plotted against their $\mathrm{O}_{\text {ads }} /\left(\mathrm{O}_{\mathrm{ads}}+\mathrm{O}_{\text {latt }}\right)$

Table 5

Quantified XPS results of catalysts with different $\mathrm{CuO}$ loadings.

\begin{tabular}{|c|c|c|c|c|c|}
\hline \multirow{2}{*}{ Catalyst } & \multicolumn{2}{|c|}{$\mathrm{O}_{\mathrm{ads}}$} & \multicolumn{2}{|c|}{$\mathrm{O}_{\text {latt }}$} & \multirow{2}{*}{$\begin{array}{c}\mathrm{O}_{\mathrm{ads}} /\left(\mathrm{O}_{\mathrm{ads}}+\mathrm{O}_{\text {latt }}\right) \\
(\%)\end{array}$} \\
\hline & B.E. $(\mathrm{eV})$ & Amount (a.u.) & B.E. $(\mathrm{eV})$ & Amount (a.u.) & \\
\hline $\mathrm{SnO}_{2}$ & 532.3 & 24 & 531.1 & 81 & 22.9 \\
\hline $1 \% \mathrm{CuO} / \mathrm{SnO}_{2}$ & 532.0 & 39 & 530.6 & 100 & 28.1 \\
\hline $3 \% \mathrm{CuO} / \mathrm{SnO}_{2}$ & 531.8 & 48 & 530.6 & 98 & 32.9 \\
\hline $5 \% \mathrm{CuO} / \mathrm{SnO}_{2}$ & 531.9 & 51 & 530.6 & 91 & 35.9 \\
\hline $7 \% \mathrm{CuO} / \mathrm{SnO}_{2}$ & 531.7 & 52 & 530.6 & 93 & 35.8 \\
\hline $9 \% \mathrm{CuO} / \mathrm{SnO}_{2}$ & 531.7 & 48 & 530.5 & 86 & 35.8 \\
\hline
\end{tabular}


percentages in Fig. 11(B). Interestingly, below 5\% CuO loading, with the increase in the $\mathrm{O}_{\text {ads }} /\left(\mathrm{O}_{\text {ads }}+\mathrm{O}_{\text {latt }}\right)$ percentages, both the $T_{\mathrm{i}}$ and $T_{\mathrm{p}}$ of the catalysts follow the same trend in that they decrease. When the CuO loading is above $5 \%$ and the $\mathrm{O}_{\text {ads }} /\left(\mathrm{O}_{\text {ads }}+\mathrm{O}_{\text {latt }}\right)$ percentages of all the samples become constant, the $T_{\mathrm{i}}$ and $T_{\mathrm{p}}$ of the catalysts also remain unchanged. Therefore, it is rational to propose that the amount of the loosely bounded surface oxygen sites might play a critical role in determining the soot combustion activities of the catalysts.

\subsection{Soot-TPR studies of the catalysts}

To examine more directly the interaction of soot particles with the surface-active sites of the $\mathrm{CuO} / \mathrm{SnO}_{2}$ catalysts, they were subjected to soot-TPR tests, and the results are displayed in Fig. 12 and Table 6. The pure $\mathrm{SnO}_{2}$ support without $\mathrm{CuO}$ displays two soot reduction peaks at 200 and $370{ }^{\circ} \mathrm{C}$, testifying the presence of two kinds of surface sites that can react with soot particulates [36]. With the addition of $\mathrm{CuO}$, both the reduction peaks become larger (Table 6), and the high-temperature peak shifts downward to $340{ }^{\circ} \mathrm{C}$, suggesting the formation of a large amount of highly active surface oxygen species due to the interaction between the dispersed surface $\mathrm{CuO}$ and the $\mathrm{SnO}_{2}$ support. Our previous results have demonstrated that for bare $\mathrm{CuO}$ prepared by using different copper precursors and precipitants, four types of oxygen sites that can react with soot particles are present [27]. However, by dispersing $\mathrm{CuO}$ onto $\mathrm{SnO}_{2}$ support, even with the formation of $\mathrm{CuO}$ micro-crystallites above the monolayer dispersion capacity, only two kinds of

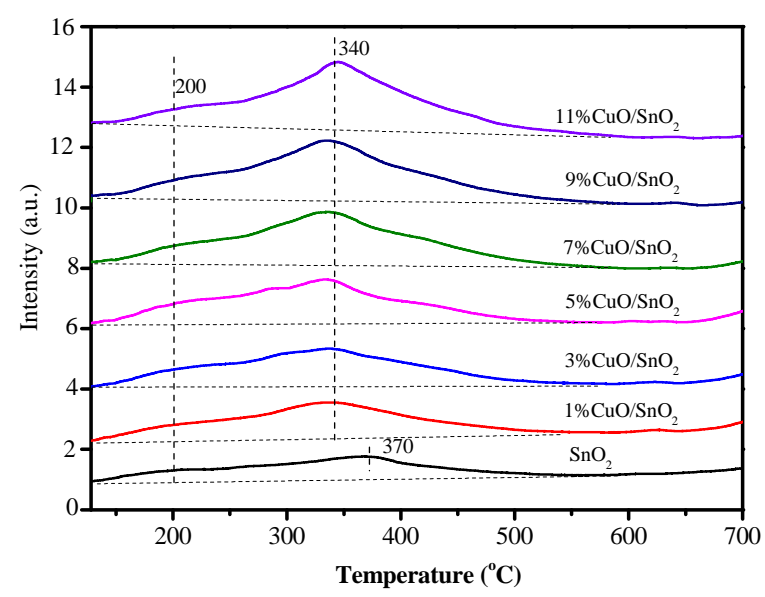

Fig. 12. Soot-TPR profiles of catalysts with different $\mathrm{CuO}$ loadings.

Table 6

Quantitative results of the measurement of soot-TPR profiles.

\begin{tabular}{lc}
\hline Catalyst & Amount of $\mathrm{CO}_{2}$ formed (a.u.) \\
\hline $\mathrm{SnO}_{2}$ & 140 \\
$1 \% \mathrm{CuO} / \mathrm{SnO}_{2}$ & 218 \\
$3 \% \mathrm{CuO} / \mathrm{SnO}_{2}$ & 238 \\
$5 \% \mathrm{CuO} / \mathrm{SnO}_{2}$ & 261 \\
$7 \% \mathrm{CuO} / \mathrm{SnO}_{2}$ & 305 \\
$9 \% \mathrm{CuO} / \mathrm{SnO}_{2}$ & 323 \\
$11 \% \mathrm{CuO} / \mathrm{SnO}_{2}$ & 335 \\
\hline
\end{tabular}

surface-active oxygen sites are observed in the lower-temperature region, as evidenced by the soot-TPR profiles of the $\mathrm{CuO} / \mathrm{SnO}_{2}$ catalysts. Apparently, owing to the interaction between $\mathrm{CuO}$ and $\mathrm{SnO}_{2}$, the property of the active sites has been changed. In brief, the soot-TPR results are in agreement with the Raman, $\mathrm{O}_{2}$-TPD, and XPS results, indicating that by dispersing $\mathrm{CuO}$ onto $\mathrm{SnO}_{2}$ support, more abundant and active oxygen species can be formed that benefits the soot combustion activities of the catalysts.

\section{Conclusions}

With the objective to design and prepare more applicable catalysts for soot combustion, a series of $\mathrm{CuO} / \mathrm{SnO}_{2}$ catalysts with different $\mathrm{CuO}$ loadings have been prepared by impregnation method to investigate the structure-reactivity relationship, which was also characterized by different means.

(1) By using XRD and XPS extrapolation methods, it was discovered that $\mathrm{CuO}$ disperses finely on the $\mathrm{SnO}_{2}$ support surface to form a monolayer with a capacity of $2.09 \mathrm{mmol} 100 \mathrm{~m}^{-2}$, which equals to $4.8 \mathrm{wt} \% \mathrm{CuO}$ loading. As testified by HR-TEM, STEM mapping, and $\mathrm{H}_{2}$-TPR results, when the $\mathrm{CuO}$ loading is below the monolayer dispersion capacity, $\mathrm{CuO}$ is present in a sub-monolayer amorphous state. On the other hand, when the loading is above the monolayer dispersion capacity, $\mathrm{CuO}$ micro-crystallites are formed, which coexist with the $\mathrm{CuO}$ monolayer.

(2) The soot combustion activity of the catalyst increases with $\mathrm{CuO}$ loading until it reaches the monolayer dispersion capacity. Further increase in the $\mathrm{CuO}$ loading has no evident influence on the activity. Therefore, an apparent monolayer dispersion threshold effect is observed for soot combustion over $\mathrm{CuO} / \mathrm{SnO}_{2}$ catalysts.

(3) Raman results have testified that with the addition of $\mathrm{CuO}$ onto $\mathrm{SnO}_{2}$ support, surface-active oxygen sites can be formed. $\mathrm{O}_{2}$-TPD and XPS results have proved that the amount of the surface oxygen species increases significantly with the increase in the $\mathrm{CuO}$ loading until it reaches the monolayer capacity. Further increase in the $\mathrm{CuO}$ loading has no evident impact on this amount. This is highly consistent with the activities of the catalysts. Therefore, the amount of surface-active oxygen sites is believed to be the main factor influencing the activities of the catalysts.

\section{Acknowledgments}

This work is supported by the National Natural Science Foundation of China $(21567016,21666020)$, the Natural Science Foundation of Jiangxi Province (20181ACB20005, 20171BAB213013, 20181BCD40004, 20181BAB203017), the Innovation Fund Designated for Graduate Students of Jiangxi Province (YC2018-B015), the Education Department Foundation of Jiangxi Province (KJLD14005), and the Opening Fund of Key Laboratory of Process Analysis and Control of Sichuan Universities (2017002), which are greatly acknowledged by the authors. 


\section{References}

[1] Z. Zhang, Y. Zhang, Z. Wang, X. Gao, J. Catal., 2010, 271, 12-21.

[2] L. Castoldi, R. Matarrese, L. Lietti, P. Forzatti, Appl. Catal. B, 2009, 90, 278-285.

[3] R. A. Kerr, Science, 2013, 339, 382.

[4] J. Oi-Uchisawa, A. Obuchi, R. Enomoto, J. Xu, T. Nanba, S. Liu, S. Kushiyama, Appl. Catal. B, 2001, 32, 257-268.

[5] Y. Wei, J. Liu, Z. Zhao, Y. Chen, C. Xu, A. Duan, G. Jiang, H. He, Angew. Chem. Int. Ed., 2011, 50, 2326-2329.

[6] M. Piumetti, B. van der Linden, M. Makkee, P. Miceli, D. Fino, N. Russo, S. Bensaid, Appl. Catal. B, 2016, 199, 96-107.

[7] Y. Liu, Y. Xie, J. Ming, J. Liu, Y. Tang, Chin. J. Catal., 1982, 3, 262-267.

[8] L. Gui, Q. Guo, Y. Xie, Y. Tang, Sci. China, Ser. B, 1984, 1, 1-9.

[9] Y. Xie, Y. Tang, Adv. Catal., 1990, 37, 1-43.

[10] L. Dong, Y. Chen, J. Chem. Soc., Faraday Trans., 1996, 92, 4589-4593.

[11] L. Dong, Y. Hu, M. Shen, T. Jin, J. Wang, W. Ding, Y. Chen, Chem. Mater., 2001, 13, 4227-4232.

[12] H. Zhu, Y. Wu, X. Zhao, H. Wan, L. Yang, J. Hong, Q. Yu, L. Dong, Y. Chen, C. Jian, J. Wei, P. Xu, J. Mol. Catal. A, 2006, 243, 24-30.

[13] D. Li, Q. Yu, S. Li, H. Wan, L. Liu, L. Qi, B. Liu, F. Gao, L. Dong, Y. Chen, Chem. Eur. J., 2011, 17, 5668-5679.

[14] G. Deo, I. E. Wachs, J. Catal., 1994, 146, 323-334.

[15] A. Baiker, D. E. Marti, P. Keusch, E. Fritsch, A. Reller, J. Catal., 1994, 146, 268-276.
[16] X. Wang, I. Wachs, Catal. Today, 2004, 96, 211-222.

[17] B. Lamb, W.C. Bray, J. C. W. Fraze, J. Ind. Eng. Chem., 1920, 213-221.

[18] Y. Liu, Y. Guo, H. Peng, X. Xu, Y. Wu, C. Peng, N. Zhang, X. Wang, Appl. Catal. A, 2016, 525, 204-214.

[19] D. A. Svintsitskiy, A. P. Chupakhin, E. M. Slavinskaya, O. A. Stonkus, A. I. Stadnichenko, S. V. Koscheev, A. I. Boronin, J. Mol. Catal. A, 2013, 368-369, 95-106.

[20] K. Nagase, Y. Zheng, Y. Kodama, J. Kakuta, J. Catal., 1999, 187, 123-130.

[21] V. A. Sadykov, S. F. Tikhov, N. N. Bulgakov, A. P. Gerasev, Catal. Today, 2009, 144, 324-333.

[22] S. Sun, C. Li, D. Zhang, Y. Wang, Appl. Surf. Sci., 2015, 333, 229-234.

[23] C. Yang, F. Xiao, J. Wang, X. Su, Sens. Actuat. B, 2015, 207, 177-185.

[24] Y. Li, H. Peng, X. Xu, Y. Peng, X. Wang, RSC Adv., 2015, 5, 25755-25764.

[25] H. Peng, Y. Liu, Y. Li, X. Zhang, X. Tang, X. Xu, X. Fang, W. Liu, N. Zhang , X. Wang, ChemCatChem, 2016, 8, 2329-2334.

[26] C. Rao, R. Liu, X. Feng, J. Shen, H. Peng, X. Xu, X. Fang, J. Liu, X. Wang, Chin. J. Catal., 2018, 39, 1683-1694.

[27] J. Shen, C. Rao, Z. Fu, X. Feng, J. Liu, X. Fan, H. Peng, X. Xu, C. Tan, X. Wang, Appl. Surf. Sci., 2018, 453, 204-213.

[28] M. Batzill, U. Diebold, Prog. Surf. Sci., 2005, 79, 47-154.

[29] N. Kamiuchi, K. Taguchi, T. Matsui, R. Kikuchi, K. Eguchi, Appl. Catal. B, 2009, 89, 65-72.

[30] C. Yang, X. Su, J. Wang, X. Cao, S. Wang, L. Zhang, Sens. Actuat. B, 2013, 185, 159-165.

\section{Graphical Abstract}

Chin. J. Catal., 2019, 40: 905-916 doi: S1872-2067(19)63354-1

Tuning $\mathrm{SnO}_{2}$ surface with $\mathrm{CuO}$ for soot particulate combustion: The effect of monolayer dispersion capacity on reaction performance

Jiating Shen, Xiaohui Feng, Rui Liu, Xianglan Xu, Cheng Rao, Jianjun Liu, Xiuzhong Fang, Chao Tan, Youchang Xie, Xiang Wang * Nanchang University; Jiangxi Baoan New Material Technology Corporation, LTD; Yibin University; Peking University
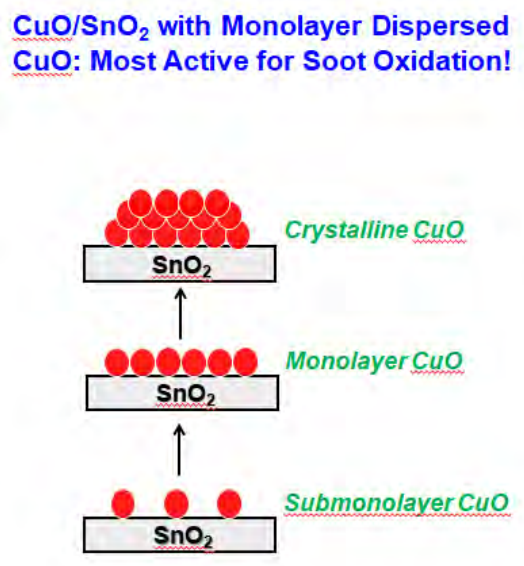

The amount of surface active oxygen sites is the major factor to control the activity of $\mathrm{CuO} / \mathrm{SnO}_{2}$ catalysts for soot combustion. An evident monolayer dispersion threshold effect is observed for the reaction performance.

\section{Monolayer dispersion} capacity for CuO?
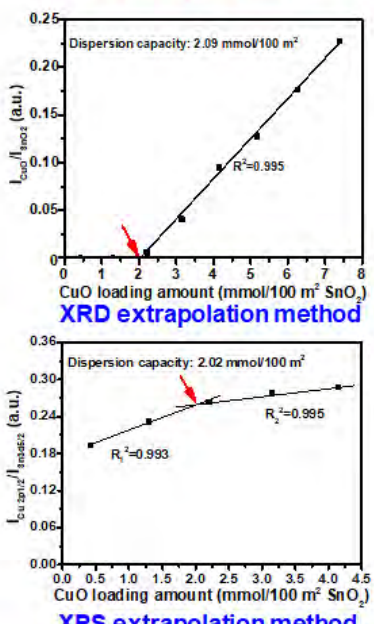

XPS extrapolation method 
[31] X. Wang, J. S. Tian, Y. H. Zheng, X. L. Xu, W. M. Liu, X. Z. Fang, ChemCatChem, 2014, 6, 1604-1611.

[32] J. Choi, H. Oh, S. W. Han, S. Ahn, J. Noh, J. B. Park, Curr. Appl. Phys., 2017, 17, 137-145.

[33] H. F. Goldstein, D. S. Kim, P. Y. Yu, L. C. Bourne, J. P. Chaminade, L. Nganga, Phys. Rev. B, 1990, 41, 7192-7194.

[34] S. H. Sun, G. W. Meng, G. X. Zhang, T. Gao, B. Y. Geng, L. D. Zhang, J. Zuo, Chem. Phys. Lett., 2003, 376, 103-107.

[35] C. H. Shek, G. M. Lin, J. K. L. Lai, Nanostruct. Mater., 1999, 11, 831-835.

[36] C. Rao, J. Shen, F. Wang, H. Peng, X. Xu, H. Zhan, X. Fang, J. Liu, W.
Liu, X. Wang, Appl. Surf. Sci., 2018, 435, 406-414.

[37] I. E. Wachs, Catal. Today, 1996, 27 437-455.

[38] A. Kim, D. P. Debecker, F. Devred, V. Dubois, C. Sanchez, C. Sassoye, Appl. Catal. B, 2018, 220, 615-625.

[39] S. Wang, B. S. Haynes, Catal. Commun., 2003, 4, 591-596.

[40] H. Peng, Y. Liu, Y. Guo, J. Zhang, L. Zhang, S. Zhou, X. Xu, W. Liu, N. Zhang, X. Wang, ChemCatChem, 2016, 8, 3714-3719.

[41] Y. Liu, Y. Guo, Y. Liu, X. Xu, H. Peng, X. Fang, X. Wang, Appl. Surf. Sci., 2017, 420, 186-195.

[42] N. S. Ramgir, I. S. Mulla, K. P. Vijayamohanan, J. Phys. Chem. B, 2005, 109, 12297-12303.

\title{
$\mathrm{CuO}$ 调配 $\mathrm{SnO}_{2}$ 表面用于碳烟颗粒燃烧：单层分散阈值效应对催化性能的影响
}

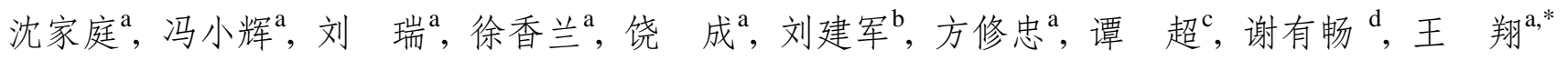 \\ a南昌大学化学学院, 江西南昌330031 \\ b 江西宝安新材料科技有限公司, 江西萍乡 337000 \\ c宜宾学院, 过程分析与控制四川省高校重点实验室, 四川宜宾644000 \\ ${ }^{d}$ 北京大学化学与分子工程学院, 北京1000871
}

\begin{abstract}
摘要: 柴油发动机由于具有良好的动力和经济性等优势而得到广泛的应用, 但排放的尾气中碳烟颗粒物(PM)却给人类健 康和环境带来了严重的危害. 目前PM污染的治理引起了广大科研工作者的关注. 催化燃烧成为PM污染消除技术中最有 效的方法.

金属氧化物负载到载体上时, 通常会出现单层分散现象, 其单层分散容量可以通过XRD, XPS和Raman等外推法测定. 此外, 当负载体系用作某种反应的催化剂时, 往往会表现出单层分散阈值效应, 即阈值附近的催化剂通常具有较高的活性 和选择性等. 目前单层分散理论已被广泛接受, 成为设计高性能催化材料的重要指导思想.

在过去八年本课题组将 $\mathrm{SnO}_{2}$ 基催化材料用于多种环保和能源反应, 并系统地探究了其催化性能. 结果表明, $\mathrm{SnO}_{2}$ 含有 丰富的表面活泼氧和晶格氧, 且热稳定性高, 是一种优良的催化剂载体. 基于单层分散理论, 为获得更实用的PM燃烧催化 剂, 我们利用浸渍法设计制备了系列不同 $\mathrm{CuO}$ 负载量的 $\mathrm{CuO} / \mathrm{SnO}_{2}$ 催化剂, 并使用XRD, XPS, Raman, TEM, STEM-mapping, $\mathrm{H}_{2}$-TPR, soot-TPR和 $\mathrm{O}_{2}$-TPD等手段深入研究了其构效关系. 利用XRD和XPS外推法测得的 $\mathrm{CuO}$ 高度分散在 $\mathrm{SnO}_{2}$ 载体表面, 其单层分散阈值为 $2.09 \mathrm{mmol} 100 \mathrm{~m}^{-2}$, 即相当于 $4.8 \% \mathrm{CuO}$ 负载量. 低于该负载量时, $\mathrm{CuO}$ 以亚单层分散态存在; 而高于该 负载量时, 形成的 $\mathrm{CuO}$ 微晶和单层分散态的 $\mathrm{CuO}$ 共存. 在单层分散阈值之前, 催化剂的碳烟燃烧活性随 $\mathrm{CuO}$ 负载量的升高 而上升; 进一步提高 $\mathrm{CuO}$ 负载量对其活性无明显的影响. Raman结果表明, 在单层分散阈值之前, $\mathrm{CuO}$ 负载到 $\mathrm{SnO}_{2}$ 载体上 可有效形成表面活泼氧中心, 且其含量随 $\mathrm{CuO}$ 负载量升高而增加; 进一步提高 $\mathrm{CuO}$ 负载量则对其含量无明显改变. 因此, $\mathrm{CuO} / \mathrm{SnO}_{2}$ 催化剂用于碳烟颗粒燃烧具有明显的阈值效应. 以上结果表明, 表面活泼氧中心含量是决定该催化剂活性的主 要因素.
\end{abstract}

关键词: 氧化锡负载的氧化铜; 碳烟颗粒燃烧; 单层分散; XRD和XPS外推法; 阈值效应

收稿日期: 2019-01-29. 接受日期: 2019-03-12. 出版日期: 2019-06-05.

*通讯联系人. 电话: 15979149877; 电子信箱: xwang23@ncu.edu.cn

基金来源：国家自然科学基金(21567016, 21666020); 江西省自然科学基金(20181ACB20005, 20171BAB213013, 20181BCD40004, 20181BAB203017); 江西省研究生创新基金(YC2018-B015); 江西省教育厅基金(KJLD14005); 四川省高校过程分析与控制重点 实验室开放基金(2017002).

本文的电子版全文由Elsevier出版社在ScienceDirect上出版(http://www.sciencedirect.com/science/journal/18722067). 